\title{
PELATIHAN MEMBUAT VPN \\ MENGGUNAKAN LAYANAN CLOUD COMPUTING SMK MA'ARIF NU 1 KEMBARAN, BANYUMAS
}

\author{
Agus Priyanto', Ipam Fuadina Adam² \\ ${ }^{12}$ Institut Teknologi Telkom Purwokerto \\ ${ }^{1}$ agus_priyanto@ittelkom-pwt.ac.id; ${ }^{2}$ ipam@ittelkom-pwt.ac.id
}

\begin{abstract}
Cloud computing is a technology that has powerful computing resources that can be applied to many organizations by using dynamic scalability as a virtual service source via the internet. SMK Ma'arif NU 1 Kembaran has a 2013 TKJ curriculum. The curriculum has topics such as Computer Assembly, Network Operating Systems and Server Administration. In the subject of Network Operating Systems, there is no subject that discusses cloud computing technology. This technology will have an impact on the average score of students before training to make VPN with cloud computing, namely 83, 12 and after training to 89.06 so that there is a descriptive increase. The hypothesis used is a two-way hypothesis so that it uses two tails with the result t table that is 2.039513 with a p value of 0.01249 . Because the $p$ value is smaller than alpha $5 \%$ or by looking at the value $\mid t$ count $\mid>t$ table then Ho is rejected. This means that there is a significant difference in the level of understanding of students before and after training to make VPN with cloud computing.
\end{abstract}

Keywords: Cloud Computing, VPN

\begin{abstract}
Abstrak
Cloud computing menjadi sebuah teknologi yang memiliki sumberdaya komputasi powerfull dapat diterapkan bagi banyak organisasi dengan penggunaan skalabilitas dinamis sebagai sumber layanan virtual melalui internet. SMK Ma'arif NU 1 Kembaran memiliki kurikulum TKJ tahun 2013. Dalam kurikulum tersebut mempunyai pokok bahasan seperti Perakitan Komputer, Sistem Operasi Jaringan dan Administrasi Server. Dalam pokok bahasan Sistem Operasi Jaringan belum ditemukannya adanya pokok bahasan yang membahas tentang teknologi komputasi awan (cloud computing). Teknologi ini akan memiliki dampak Ratarata nilai siswa sebelum adanya pelatihan membuat VPN dengan cloud computing yaitu 83,12 dan setelah pelatihan menjadi 89.06 sehingga ada peningkatan secara deskriptfif. Hipotesis yang digunakan yaitu hipotesis dua arah sehingga menggunakan two tail dengan hasilnya $t$ tabel yaitu 2.039513 dengan $p$ value sebesar 0.01249. Karena $p$ value lebih kecil dari alfa $5 \%$ atau dengan melihat nilai $\mid t$ hitung $\mid>t$ tabel maka Ho ditolak. Hal ini berarti ahwa terdapat perbedaan tingkat pemahaman siswayang signifikan sebelum dan sesudah pelatihan membuat VPN dengan cloud computing.
\end{abstract}

Kata Kunci: Cloud Computing, VPN 


\section{PENDAHULUAN}

Cloud computing menjadi sebuah teknologi yang memiliki sumberdaya komputasi powerfull dapat diterapkan bagi banyak organisasi dengan penggunaan skalabilitas dinamis sebagai sumber layanan virtual melalui internet. Teknologi ini akan memiliki dampak yang signifikan pada lingkungan pendidikan dan dapat menjadi alternatif bagi lembaga pendidikan yang memiliki anggaran terbatas dapat meningkatkan efisiensi penghematan biaya dalam mengoperasikan sistem informasi secara efektif tanpa mengeluarkan modal lebih untuk menyediakan banyak komputer dan perangkat jaringan (Ercan, 2010).

Menurut National Institute of Standards and Technology (NIST) komputasi awan (cloud computing) adalah sebuah bentuk layanan yang membuka peluang untuk dapat hadir dimanapun, memberikan kenyamanan, akses jaringan sesuai permintaan (ondemand) ke lokasi sumber daya komputasi terkonfigurasi (misalnya, jaringan, server, penyimpanan, aplikasi dan layanan), yang dapat dengan cepat dijalankan dan diluncurkan, dengan upaya pengelolaan minimal atau dengan menggunakan penyedia jasa layanan (Mell dan Grance, 2011).

Sekolah SMK Ma'arif NU 1 Kembaran adalah lembaga pendidikan swasta yang beralamat di jalan Pondok Pesantren Mamba'ul Ushulil Hikmah Bakung, Linggasari, Kembaran, Purwokerto yang bernaung dibawah yayasan LP Ma'arif. SMK Ma'arif NU 1 Kembaran mendidik siswa menjadi terampil, religi, dan berakhlakul karimah. SMK Ma'arif NU 1 Kembaran mempunyai beberapa Program Keahlian yaitu : Teknik Kendaraan Ringan, Tata Busana, Teknik Komputer Jaringan.

Dalam menjalankan aktifitas pendidikannya SMK Ma'arif NU 1 Kembaran memiliki kurikulum TKJ tahun 2013. Dalam kurikulum tersebut mempunyai pokok bahasan seperti Perakitan Komputer, Sistem Operasi Jaringan dan Administrasi Server. Dalam pokok bahasan Sistem Operasi Jaringan belum ditemukannya adanya pokok bahasan yang membahas tentang teknologi komputasi awan (cloud computing).

Selain itu menurut buku 9 Mega Technology Trends bahwa Cloud computing merupakan salah satu trend teknologi saat ini. Cloud bergantung pada bandwidth internet, pertumbuhan file yang eksponensial dalam data menimbulkan masalah dalam hal penyimpanan. Pertumbuhan perangkat $I o T$, yang semuanya akan terjadi mentransmisikan data ke cloud (Marr, Bernard, 2018). 
Berdasarkan latar belakang tersebut peneliti melakukan pengabdian masyarakat dalam bentuk pelatihan tentang teknologi komputasi awan (cloud computing).

\section{METODE DAN PELAKSANAAN}

\section{Sasaran}

Sasaran kegiatan ini adalah siswa siswi SMK Ma'arif NU 1 Kembaran, mereka yang mengikuti adalah siswa siswi kelas TKJ kelas sebanyak 32.

\section{Prosedur Pelaksanaan}

Sosialisasi dan pelatihan dilakukan dengan mengikuti prosedur berikut ini:

a. Mengusulkan kegiatan Pengabdian Kepada Masyarakat ke LPPM

b. Mengurus dan menyiapkan segala kebutuhan administrasi.

c. Menyiapkan modul pelatihan

d. Melakukan sosialisasi dan pelatihan membuat VPN dengan cloud computing

e. Melakukan evaluasi terhadap keberhasilan Pengabdian Kepada Masyarakat

\section{Metode Pelaksanaa}

Pelaksanaan kegiatan pengabdian masyarakat ini, dilaksanakan di Laboratorium Komputer SMK Ma'arif NU 1 Kembaran pada :

Tanggal : Rabu, 12 Agustus 2020

Waktu : 10.00 WIB -- Selesai
Jumlah : 32 siswa

Metode pelaksanaan kegiatan pengabdian pada siswa SMK Ma'arif NU 1 Kembaran apat dilihat bagan bagan dibawah ini

1. Siswa SMK Ma'arif NU 1 Kembaran sudah memahami jaringan dasar

2. Siswa SMK Ma'arif NU 1 Kembaran belum mengetahui teknologi komputasi awan (cloud computing)

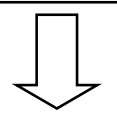

1. Memberikan pemahaman dasar tentang teknologi komputasi awan (cloud computing)

2. Memberikan pelatihan membuat VPN dengan cloud computing

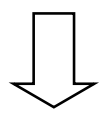

1. Modul pelatihan

2. Pendampingan pelatihan membuat VPN dengan cloud computing

3. Laporan pengabdian

Gambar 1. Metode Pelaksanaan Kegiatan

\section{HASIL DAN PEMBAHASAN}

\section{Hasil Kegiatan}

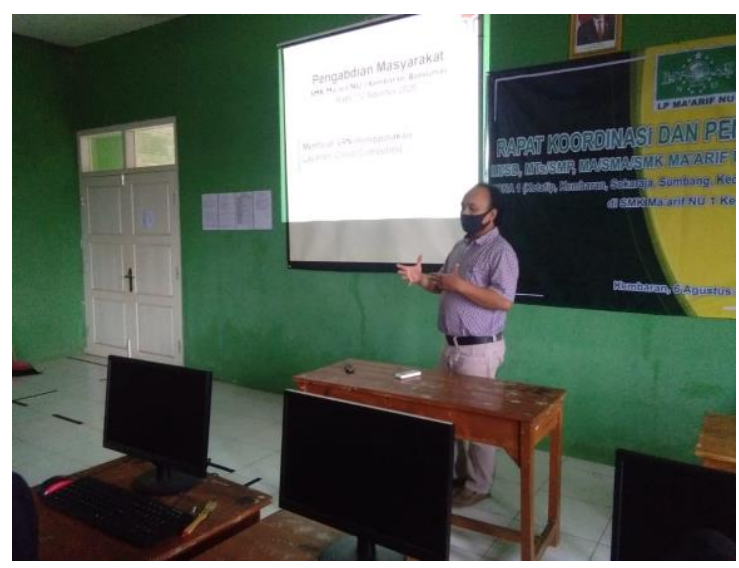

Gambar 2. Penyampaian Materi Cloud Computing 


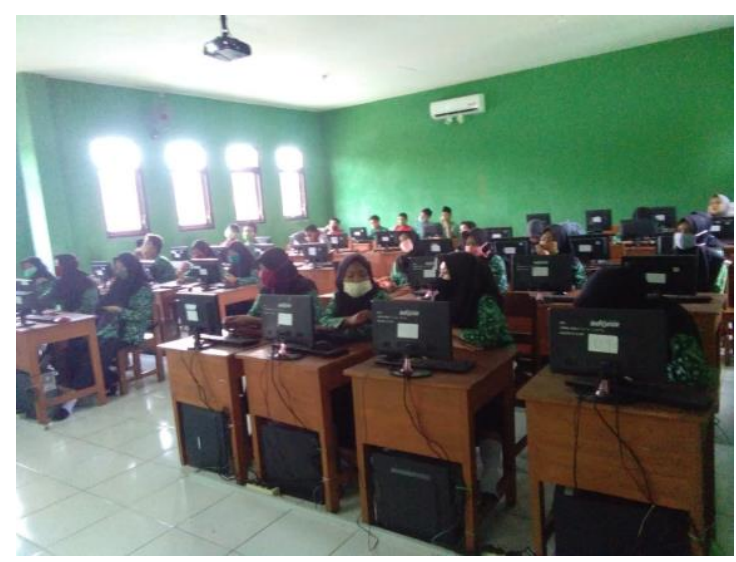

Gambar 3. Penyampaian Materi VPN

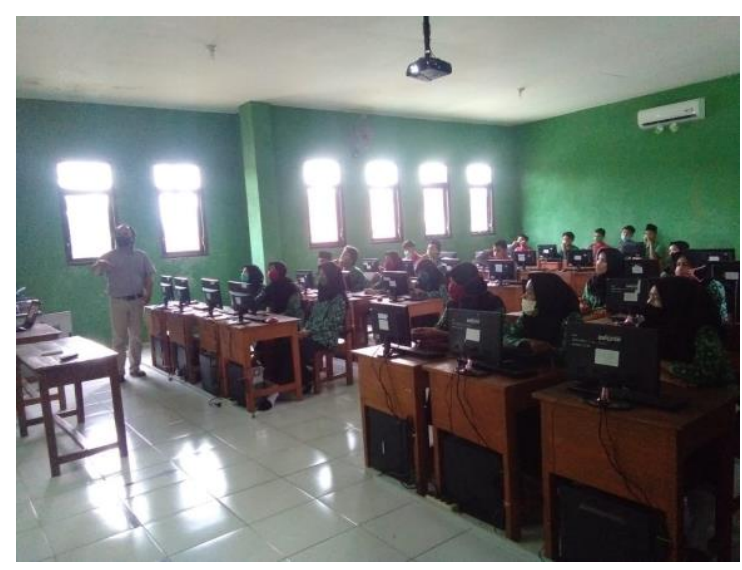

Gambar 4. Peserta Membuat VPN dengan Cloud Computing

\section{Pembahasan}

Berikut pembahasan dalam pelatihan yang telah dilakukan selama 3 jam, dengan 32 siswa pelatihan. Untuk mengukur tingkat pemahaman siswa akan dilakukan dengan menggunakan test dilakukan sebelum pelatihan (pretest), kemudian memberikan pelatihan membuat VPN dengan cloud computing.

Dalam sesi terakhir peneliti memberikan memberikan test setelah pelatihan (post test) untuk mengetahui peningkatan pemahaman siswa dalam pelatihan ini dengan menggunakan instrument dalam bentuk kuis dan memperoleh hasil nilai sebagai berikut.

Tabel 1. Nilai Pre Test dan Post Test

\begin{tabular}{|c|c|c|}
\hline Responden & N_PreTest & N_PostTest \\
\hline R1 & 70 & 70 \\
\hline R2 & 90 & 80 \\
\hline R3 & 80 & 90 \\
\hline R4 & 80 & 100 \\
\hline R5 & 100 & 90 \\
\hline R6 & 80 & 100 \\
\hline R7 & 70 & 100 \\
\hline R8 & 80 & 80 \\
\hline R9 & 80 & 100 \\
\hline R10 & 100 & 90 \\
\hline R11 & 100 & 100 \\
\hline R12 & 80 & 70 \\
\hline R13 & 90 & 70 \\
\hline R14 & 90 & 80 \\
\hline R15 & 70 & 80 \\
\hline R16 & 80 & 80 \\
\hline R17 & 80 & 100 \\
\hline R18 & 80 & 80 \\
\hline R19 & 80 & 80 \\
\hline R20 & 80 & 100 \\
\hline R21 & 80 & 90 \\
\hline R22 & 70 & 70 \\
\hline R23 & 80 & 100 \\
\hline R24 & 80 & 100 \\
\hline R25 & 80 & 100 \\
\hline R26 & 100 & 100 \\
\hline R27 & 60 & 80 \\
\hline R28 & 100 & 100 \\
\hline R29 & 90 & 90 \\
\hline R30 & 80 & 80 \\
\hline R31 & 80 & 100 \\
\hline R32 & 100 & 100 \\
\hline & & \\
\hline & & \\
\hline
\end{tabular}

Peneliti mempunyai hipotesis untuk melihat tingkat pemahaman siswa terhadap teknologi cloud computing, yaitu:

$\mathrm{H}_{\mathrm{o}}$ : Tidak ada perbedaan tingkat 
pemahanan siswa yang signifikan, sebelum dan sesudah pelatihan.

$\mathrm{H}_{1}$ : Adanya perbedaan tingkat pemahanan siswa yang signifikan, sebelum dan sesudah pelatihan.

Untuk menjawab hipotesis tersebut, peneliti menggunakan Uji $\mathrm{T}$ Paired (berpasangan). Uji T Paired (berpasangan) sering kali disebut sebagai paired-sampel t test. Uji t untuk data sampel berpasangan dengan membandingkan $n$ rata-rata 2(dua) variabel untuk suatu grup sampel tunggal. Uji ini menghitung selisih antara nilai 2(dua) variabel untuk tiap kasus dan menguji apakah selisih ratarata tersebut bernilai nol (Siregar , 2013).

Berikut merupakan hasil pengolahan data menggunakan Uji $\mathrm{T}$ Paired.

Tabel 2. Hasil Uji T Paired

\begin{tabular}{lrr}
\multicolumn{3}{c}{ t-Test: Paired Two Sample for Means } \\
\hline & N_PreTest & N_PostTest \\
\hline Mean & 83.125 & 89.0625 \\
Variance & 106.0483871 & 124.8991935 \\
Observations & 32 & 32 \\
Pearson Correlation & 0.306566377 \\
Hypothesized Mean Difference & 0 & \\
df & 31 & \\
t Stat & -2.652157785 \\
P(T<=t) one-tail & 0.006246319 \\
t Critical one-tail & 1.695518742 \\
P(T<=t) two-tail & 0.012492639 \\
t Critical two-tail & 2.039513438 \\
\hline
\end{tabular}

Rata-rata nilai siswa sebelum adanya pelatihan membuat VPN dengan cloud computing yaitu 83, 12 dan setelah pelatihan menjadi 89.06 sehingga ada peningkatan secara deskriptfif.

Selain itu dengan melihat deskriptif berupa korelasi pearson yaitu 0.306 yang bernilai postif sehingga bisa dikatakan hubungan sangat erat.

Hipotesis yang digunakan yaitu hipotesis dua arah sehingga menggunakan two tail dengan hasilnya $t$ tabel yaitu 2.039513 dengan $p$ value sebesar 0.01249. Karena $p$ value lebih kecil dari alfa $5 \%$ atau dengan melihat nilai $\mid t$ hitung $\mid>$ t tabel maka Ho ditolak. Hal ini berarti ahwa terdapat perbedaan tingkat pemahaman siswa yang signifikan sebelum dan sesudah pelatihan membuat VPN dengan cloud computing.

\section{PENUTUP}

\section{Simpulan}

Kesimpulan yang didapatkan dari hasil pengabdian pada siswa SMK Ma'arif NU 1 Kembaran adalah sebagai berikut;

a. Bahwa rataan tingkat pemahaman siswa tentang teknologi Cloud Computing sebelum ada pelatihan yaitu sebesar 83.12

b. Bahwa rataan tingkat pemahaman siswa tentang teknologi Cloud Computing sesudah ada pelatihan yaitu sebesar 89.06

c. Dengan melihat nilai $t$ tabel yaitu 2.039513 dengan $p$ value sebesar 
o.01249. Oleh karena $p$ value lebih kecil dari alfa $5 \%$ atau dengan melihat nilai $\mid t$ hitung $\mid>t$ tabel maka Ho ditolak. Hal ini berarti bahwa terdapat perbedaan tingkat pemahaman siswa yang signifikan sebelum dan sesudah pelatihan membuat VPN dengan cloud computing.

\section{Saran}

Saran peneliti untuk keberlanjutan kegiatan pengabdian masyarakat ini khususnya dalam teknologi cloud computing adalah dengan pelatihan membuat aplikasi yang bermanfaat bagi masyarakat dengan memanfaatkan teknologi cloud computing .

\section{Ucapan Terima Kasih}

Penulis mengucapkan terima kasih kepada Dekan Fakultas Informatika, Ketua Prodi S1 Informatika dan LPPM IT Telkom Purwokerto serta Kepala Sekolah SMK Ma'arif NU 1 Kembaran berserta jajarannya yang telah memberikan dukungan untuk kegiatan pengabdian ini.

\section{DAFTAR PUSTAKA}

Ercan. 2010. Effective use of cloud computing in educational institutions. Procedia - Social and Behavioral Sciences. Vol 2, 938942. Mell, Grance. 2011.

The NIST Definition of Cloud Computing Recommendations of the National Institute of Standards and Technology. NIST Special Publication 800- 145 .

Marr, Bernard, 2018. 9 Mega Technology Trends. Bernard Marr \& Co. Intelligent Business Performance Siregar, S. (2013). Metode Penelitian Kuantitatif dilengkapi dengan perbandingan, perhitungan, manual \&SPSS. Jakarta: PT Fajar Interpratama Mandiri. 